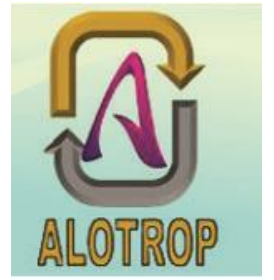

\title{
PENERAPAN KEMOMETRIK PADA METODE CITRA DIGITAL UNTUK ANALISIS ION MERKURI (II) DENGAN INDIKATOR NANOPARTIKEL PERAK
}

\author{
Angga Aprian Dinata*1, M. Lutfi Firdaus ${ }^{2}$, Rina Elvia ${ }^{3}$ \\ $1,2,3$ Program Studi Pendidikan Kimia, Jurusan PMIPA, FKIP \\ Universitas Bengkulu \\ * e-mail: anggaaprian13@gmail.com
}
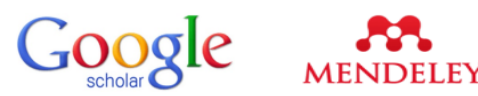

Oonesearch PKP|INDEX

Academia.edu

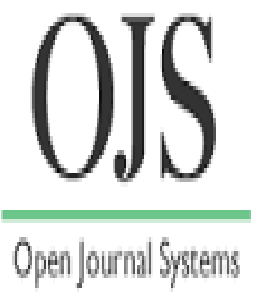

\begin{abstract}
Digital image method in quantitative analysis usually uses one of the RGB primary color components (Red, Green, Blue), so that not all digital image data can be extracted. Then needed a method that can render the whole RGB values as variables in quantitative analysis are known as chemometric. This research aims to know the influence of the application of chemometric against the sensitivity of the digital image. Chemometry method used is the Principal Component Regression (PCR) and Partial Least Square (PLS) using Unscramber X software from Camo software, USA.. This method is applied for the quantitative analysis of Mercury (II) ion with silver nanoparticles (NPP) immobilization on filter paper indicator. The research results showed that chemometric has a good influence against the level of the Limit of Detection (LOD) of the digital image, where the level of LOD with chemometric application of the Principal Component Regression (PCR) is 0.4311 ppb, and Partial Least Square (PLS) is $0.4310 \mathrm{ppb}$ smaller than without the application of chemometric Single Linear Regression (SLR) at 0.837 ppb.
\end{abstract}

Keywords: Digital Image, chemometric, mercury, silver nanoparticles

\begin{abstract}
ABSTRAK
Metode citra digital dalam analisis kuantitatif pada umunya menggunakan hanya salah satu komponen warna primer RGB (Red, Green, Blue), sehingga tidak mampu dalam mengekstrak semua data citra digital yang ada. Karena hal tersebut dibutuhkan suatu metode yang dapat menjadikan seluruh nilai RGB sebagai variabel dalam analisis kuantitatif (kemometrik). Penelitian ini bertujuan untuk mengetahui pengaruh penerapan kemometrik terhadap tingkat sensitivitas dari metode citra digital. Metode kemometrik yang digunakan adalah metode Principal Component Regression (PCR) dan Partial Least Square (PLS) yang memanfaatkan perangkat lunak Unscramber $X$ dari Camo software, USA. Metode ini diaplikasikan dalam analisis kuantitatif dari ion $\mathrm{Hg}$ (merkuri) (II) dengan indikator nanopartikel perak (NPP) yang terimobilisasi pada kertas saring. Penelitian ini dilaksanakan di Laboratorium Pendidikan Kimia, FKIP, Universitas Bengkulu. Pelaksanaan penelitian ini dimulai pada Februari 2018 sampai dengan April 2018. Hasil penelitian menunjukan bahwa kemometrik memiliki pengaruh yang baik terhadap tingkat Limit of Detection (LOD) citra digital, dimana tingkat LOD dengan penerapan kemometrik Principal Component Regression (PCR) pada 0,4311 ppb, dan Partial Least Square (PLS) pada 0,4310 ppb lebih kecil dibandingkan tanpa penerapan kemometrik Single Linier Regression (SLR) 0,pada 837 ppb.
\end{abstract}

Kata Kunci : Citra Digital, kemometrik, merkuri, nanopartikel perak

\section{LATAR BELAKANG}

Metode analisis kuantitatif yang mulai berkembang saat ini adalah metode citra digital yang merupakan gabungan antara foto digital dan kolorimetrik [1]. Metode ini memiliki potensi yang baik dalam analisis kuantitatif dikarenakan metode ini sederhana, tidak memerlukan alat yang mahal dan memiliki potensi yang tinggi dalam analisis kolorimetrik [2].

Metode citra digital pada analisisnya menggunakan data RGB (Red, Green, Blue) dari suatu sampel yang merupakan perluasan data dari suatu sistem warna, yang diinterprestasikan sebagai pantulan cahaya suatu objek dan memiliki rentang nilai 0 sampai 225 unit [3]. Pantulan cahaya suatu objek dibaca oleh Charge Couple Detector (CCD) pada kamera digital, pantulan cahaya ini melewati filter Red, Green dan Blue yang ada di dalam CCD.

Nilai RGB sangat dipengaruhi oleh faktor pada kondisi pengambilan foto, yaitu tingkat eksposur (kecerahan), tingkat kejernihan (white balance), sumber pencahayaan, pantulan cahaya objek dan kamera. Faktor ini dapat menimbulkan tingkat kesalahan ketika warna yang sama dibandingkan dengan gambar yang berbeda [4].

Pada umumnya metode citra digital hanya menggunakan teknik analisis data sederhana yaitu Single Linier Regression (SLR), yang hanya menggunakan satu data RGB, seperti pada 
penelitian yang menggunakan data $\mathrm{B}$ (Blue) dalam analisis ion logam berat dengan nanopartikel perak sebagai indikator kolorimetrik [5]. Setiap nilai RGB memiliki informasi analitik, bila terjadi kesalahan saat pengambilan gambar dan tidak semua informasi yang ada pada data RGB digunakan, maka kesalahan dalam analisis semakin besar.

Untuk mengatasi masalah ini maka diperlukanlah suatu metode yang dapat menjadikan seluruh nilai RGB dan total nilai RGB sebagai variabel dalam analisis kuantitatif yang dikenal dengan kemometrik [6].

International Chemometrics Society (ICS) mendefinisikan kemometrik sebagai cabang ilmu kimia yang berhubungan dengan pengukuran suatu sistem kimia dengan penerapan metode matematika dan statistika [7].

Kemometrik dalam penerapanya menggunakan analisis data multivariat untuk mengolah data dengan variabel yang banyak. Ada beberapa analisis multivariat yang dapat digunakan yaitu, Principal Component Regression (PCR), dan Partial Least Square (PLS) [8].

Pada metode citra digital analisis multivariat ini berkerja dengan mereduksi dan mengkompresi data untuk mendapatkan informasi yang optimal, selain itu juga dapat mengekstrak data pelengkap dari nilai total RGB untuk meminimalisir kesalahan yang didapat dari pengambilan data sampel [9].

Dengan adanya kemometrik diharapkan dapat mengurangi kesalahan metode citra digital dalam analisis kuantitatif, dengan cara melihat perubahan nilai Limit of Detection (LOD) dari metode citra digital [10]. Salah satu analisis kuantitatif yang banyak dipelajari saat ini adalah analisis kuantitatif ion merkuri (II) khususnya pada kondisi terlarut [11], yang menggunakan Nanopartikel Perak NPP) sebagai Indikator Kolorimetri dengan Metode Spektrofotometri [12].

Analisis ion $\mathrm{Hg}^{2+}$ ini menjadi penting, mengingat merkuri merupakan logam berat yang menjadi bahan pencemaran [13]. Masuknya merkuri dalam jumlah tinggi kelingkungan perairan dapat membahayakan kesehatan manusia yang menggunakan air dan mengkonsumsi organisme tersebut. Nilai ambang batas aman merkuri dalam air minum memiliki konsentrasi maksimum $0,001 \mathrm{mg} / \mathrm{L}$ (1ppb) [14].
Pada analisis kuantitatif ion merkuri (II) diperlukan suatu indikator, yang dapat digunakan untuk menjadi detektor. Salah satu indikator yang dapat digunakan yaitu NPP terimobilisasi pada kertas saring, karena NPP memiliki tingkat selektivitas dan sensitivitas yang tinggi terhadap ion merkuri (II), sehingga dapat membantu dalam analisis kuantitatif ion merkuri (II) [15].

Selain itu penggunaan NPP terimobilisasi pada kertas saring dapat digunakan langsung di lokasi pengambilan sampel, tanpa harus mengerjakannya di dalam laboratorium [16].

Berdasarkan latar belakang di atas maka dilakukan penelitian yang berjudul "Penerapan Kemometrik pada Metode Citra Digital untuk Analisis Ion Merkuri (II) dengan Indikator Nanopartikel Perak", yang diharapkan mampu menjadi metode alternatif analisis kuantitatif yang efektif dan efisien.

\section{METODE PENELITIAN}

Penelitian ini dilaksanakan di Laboratorium Pendidikan Kimia, FKIP, Universitas Bengkulu. Pelaksanaan penelitian ini dimulai pada Februari 2018 sampai dengan April 2018.

Adapun alat yang digunakan dalam penelitian ini yaitu, gelas kimia, gelas ukur, labu ukur, pipet tetes, kaca arloji, sudip, corong kaca, batang pengaduk, botol vial, botol semprot, derigen air, neraca analitik, pipet mikro, pipet kapiler, printer canon ip2770, mini box dan kamera smarthphone Xiaomi Note 3 Pro. Aplikasi yang digunakan adalah MATLAB R2016b (The MathWork, USA), Excel (Microsoft Excel, Redmond, WA), Camera FV-5 (FGAE,Germany), Photoshop CC 2014 (Adobe Systems, USA) dan X Unscrambler 10.4 (Camo software, USA).

Adapun bahan-bahan yang digunakan dalam penelitian ini yaitu, aquades, air demineral, $\mathrm{HgCl}_{2}$, nanopartikel perak terimobilisasi pada kertas saring didapat dari stok laboratorium Pendidikan Kimia, FKIP, Universitas Bengkulu.

NPP terimobilisasi kertas pada kertas saring ditambahkan $10 \mu \mathrm{L}$ larutan stok $\mathrm{Hg}^{2+}$ dengan cara ditetesi pada media kertas saring masing-masing dengan konsentrasi $0,1,2,3$ dan 4 ppb dan konsentrasi $0,10,20,30$ dan 40 ppm. Kemudian NPP terimobilisasi pada kertas saring dibiarkan kering terlebih dahulu pada suhu 
ruangan. Setelah kering NPP terimobilisasi kertas difoto di dalam mini box untuk analisis ion merkuri (II). Foto/ atau gambar citra digital yang telah diperoleh dengan cara, foto sampel yang dianalisis dicrop dengan ukuran 200 x 200 pixel pada masing masing sampel menggunakan program Photoshop CC 2014. Kemudian dianalisis menggunakan program MATLAB R2016b, hasil analisis berupa nilai komponen warna RGB.

Kurva kalibrasi citra digital dibuat dengan cara mengolah terlebih dahulu nilai komponen warna RGB dikonversi menjadi intensitas RGB menggunakan persamaan Lamber-Beer:

$$
A=\log I_{0} / I_{t}
$$

Keterangan :

$\mathrm{A}=$ intensitas serapan komponen warna

$I_{0}=$ Nilai intensitas kompoen warna larutan blanko

$I_{t}=$ Nilai intensitas komponen warna larutan stok Selanjutnya untuk masing-masing intensitas warna dibuat kurva kalibrasi konsentrasi vs intensitas komponen warna RGB.

\section{HASIL DAN PEMBAHASAN}

Pada penelitian ini dirancanglah suatu alat yang dapat mengontrol faktor-faktor kesalahan dalam pengambilan gambar, yaitu mini box yang merupakan tempat pengambilan gambar sampel dan dirancang khusus untuk analisis ion $\mathrm{Hg}$ (II) secara citra digital.

Mini box dibuat disesuaikan dengan kamera yang digunakan [17]. Mini box ini terdiri dari beberapa bagian yaitu bentuk kubus ukuran $14 \mathrm{~cm} \mathrm{x} 14 \mathrm{~cm} \times 14 \mathrm{~cm}$, ditutupi setiap sisinya agar cahaya dari luar tidak mengganggu pada proses pengambilan gambar tempat sampel dan juga tempat kamera sejauh $10 \mathrm{~cm}$ (Gambar 1)

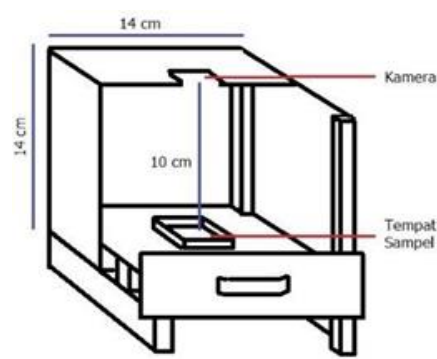

(a)

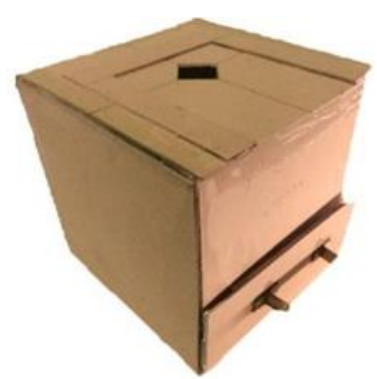

(b)
Gambar 1. (a) Sketsa mini box dan (b) Mini box

Data yang didapat dari matlab berupa intensitas komponen warna, dimasukkan kedalam excel untuk membuat tabel, konsentrasi dan intensitas komponen warna.

Dibuka aplikasi The Unscrambler X 10.4, data tabel konsentrasi dan intensitas komponen warna diimport ke dalam The Unscrambler X 10.4 dengan cara klik File, Import Data, Excel lalu pilih data excel konsentrasi dan intensitas warna.

Tabel diatur dengan menu Define Range, diatur kolom konsentrasi dan kolom absorbansi yang berisi nilai intensitas komponen warna. Lalu digunakan menu Tasks, Analyze, pilih menu Principal Component Regression untuk mengolah data secara PCR dan pilih menu Partial Least Squares Regression untuk mengolah data secara PLS. Hasil pengolahan data digunakan sebagai Training set untuk analisis ion merkuri(II).

Kamera yang digunakan dalam penelitian, yaitu kamera ponsel dari Xiaomi Note 3 pro. Ada beberapa faktor yang dapat mempengaruhi hasil gambar dari suatu foto, yaitu tingkat ISO, white balance, tingkat pencahayaan, tingkat exposure, bukaan kamera, dan juga sumber cahaya.

Untuk ponsel Xiaomi Note 3 pro digunakan pengaturan manual berupa aplikasi Camera $F V-5$, dengan pengaturan berupa ISO diatur pada tingkat 200, white balance diatur ketipe lampu pijar, mode pencahayaan penuh, dengan bukaan kamera $\mathrm{f} / 2.0$, tingkat exposure diatur pada angka 0 , bukaan kamera selama 2 detik, fokus kamera automatic dan sumber cahaya berasal dari lampu kamera ponsel yang diatur dari mode blitz kemode lampu.

Untuk gambar diatur pada ukuran pixel sebesar 3.1 MP dengan rasio (4:3), dan gambar yang dihasilkan berformat. .JPEG.

Dari mini box yang telah dibangun dan dibantu dengan aplikasi manual Camera $F V-5$, hasil gambar yang diperoleh dikrop dengan ukuran 200 x 200 pixel lalu dianalisis menggunakan aplikasi Matlab R217b,dan didapatlah hasil data nilai komponen warna RGB pada pengulangan pengambilan gambar suatu sampel (Tabel 1)

Dari Tabel 1 terlihat bahwa untuk disetiap pengulangan pengambilan dari gambar akan memiliki tingkat perbedaan yang kecil, sehingga penggunaan mini box dan aplikasi manual dari Camera FV-5 dapat mengatasi faktor yang mempengaruhi pengambilan gambar citra.. 
Tabel 1. Data nilai komponen warna RGB dari Pengulangan Pengambilan Gambar pada Mini Box

\begin{tabular}{|c|c|c|c|}
\hline Pengulangan & R & G & B \\
\hline 1 & 152,23 & 143,12 & 106,62 \\
\hline 2 & 152,17 & 143,35 & 107,54 \\
\hline 3 & 152,29 & 143,11 & 106,97 \\
\hline
\end{tabular}

Pada analisis ion $\mathrm{Hg}$ (II) digunakan indikator NPP terimobilisasi pada kertas saring, dilakukan dengan cara menambahkan $10 \mu \mathrm{L}$ larutan stok $\mathrm{Hg}^{2+}$ dengan konsentrasi ppb dan ppm.

Untuk konsentrasi ppb larutan stok $\mathrm{Hg}^{2+}$ yang digunakan yaitu $0,1,2,3$ dan $4 \mathrm{ppb}$, sedangkan untuk konsentrasi ppm larutan stok $\mathrm{Hg}^{2+}$ yang digunakan $0,10,20,30$ dan 40 ppm.

Hasil penambahan larutan stok $\mathrm{Hg}^{2+}$ pada NPP terimobilisasi pada kertas saring dapat dilihat pada Gambar 2.

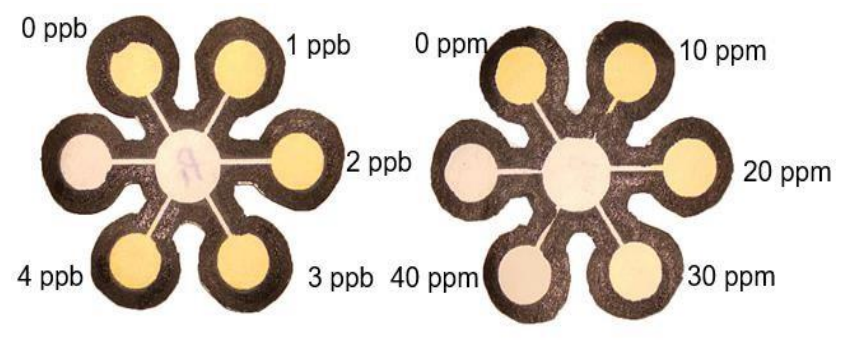

(a)

(b)

Gambar 2. NPP terimobilisasi pada kertas saring + larutanstok $\mathrm{Hg}^{2+}$.

(a) konsentrasi ppb dan

(b) konsentrasi ppm

Setelah penambahan larutan stok $\mathrm{Hg}^{2+}$, kertas difoto di dalam mini box, dan gambar dikrop dengan ukuran 200 x 200 pixel pada masing-masing sampel dan hasil kroping dianalisis menggunakan program Matlab R2016b untuk mengekstak data nilai komponen warna RGB dan dianalisis nilai komponen warna dari RGB (Tabel 2).

Dari Tabel 2. terlihat terdapat 4 data komponen warna yaitu red (R), green (G), blue (B) dan nilai RGB total (RGBtot). Semakin besar konsentrasi maka terjadi kenaikan diseluruh nilai komponen warna.

Dari data komponen warna maka dicarilah nilai intensitas (absorbansi) dari setiap komponen warna.
Tabel 2. Nilai komponen warna RGB NPP terimobilisasi pada kertas + larutan stok $\mathrm{Hg}^{2+}$ (ppm)

\begin{tabular}{|c|c|c|c|l|}
\hline \multirow{2}{*}{$\begin{array}{c}\text { Konsentrasi } \\
(\mathrm{ppm})\end{array}$} & \multicolumn{4}{|c|}{ Nilai Komponen Warna } \\
\cline { 2 - 5 } & $\mathrm{R}$ & $\mathrm{G}$ & $\mathrm{B}$ & RGBtot \\
\hline 0 & 150,969 & 141,723 & 106,466 & 399,158 \\
\hline 10 & 151,162 & 143,493 & 107,405 & 423,090 \\
\hline 20 & 153,738 & 145,355 & 110,197 & 440,278 \\
\hline 30 & 154,585 & 145,588 & 111,077 & 472,230 \\
\hline 40 & 155,322 & 148,397 & 113,144 & 488,865 \\
\hline
\end{tabular}

Dari data komponen warna maka dicarilah nilai intensitas (absorbansi) dari setiap komponen warna. Hasil nilai intensitas warna RGB NPP terimobilisasi pada kertas saring dengan penambahan larutan stok $\mathrm{Hg}^{2+}$ pada konsentrasi ppm dapat dilihat pada tabel 3 .

Tabel 3. Nilai intensitas warna RGB NPP terimobilisasi pada kertas + larutan stok $\mathrm{Hg}^{2+}$ (ppm)

\begin{tabular}{|c|l|l|l|l|}
\hline $\begin{array}{c}\text { Konsentrasi } \\
(\mathrm{ppm})\end{array}$ & \multicolumn{4}{|c|}{ Intensitas Serapan } \\
\hline & $\mathrm{R}$ & $\mathrm{G}$ & $\mathrm{B}$ & Itot \\
\hline 0 & 0 & 0 & 0 & 0 \\
\hline 10 & 0,554 & 11,401 & 74,656 & 86,613 \\
\hline 20 & 7,893 & 13,967 & 119,498 & 141,351 \\
\hline 30 & 10,279 & 32,085 & 190,423 & 232,783 \\
\hline 40 & 12,345 & 34,376 & 228,486 & 275,207 \\
\hline
\end{tabular}

Nilai komponen warna NPP terimobilisasi pada kertas saring dengan penambahan larutan stok $\mathrm{Hg} 2+$ pada konsentrasi ppb (Tabel 4) dapat dilihat seperti berikut

Tabel 4. Nilai komponen warna warna RGB NPP terimobilisasi pada kertas + larutan stok $\mathrm{Hg}^{2+}(\mathrm{ppb})$

\begin{tabular}{|c|c|c|c|c|}
\hline \multirow{2}{*}{$\begin{array}{l}\text { Konsentrasi } \\
(\mathrm{ppb})\end{array}$} & \multicolumn{4}{|c|}{ Nilai Komponen Warna } \\
\cline { 2 - 5 } & $\mathrm{R}$ & $\mathrm{G}$ & $\mathrm{B}$ & RGBtot \\
\hline 0 & 150,969 & 141,723 & 106,466 & 399,158 \\
\hline 1 & 151,198 & 143,493 & 107,405 & 402,096 \\
\hline 2 & 153,739 & 145,355 & 110,197 & 409,291 \\
\hline 3 & 154,587 & 145,588 & 111,077 & 411,252 \\
\hline 4 & 156,328 & 148,397 & 113,144 & 417,869 \\
\hline
\end{tabular}


Dari Tabel 4 terlihat bahwa bila semakin besar konsentrasi maka terjadi kenaikan diseluruh nilai komponen warna. Dari data komponen warna maka dicarilah nilai intensitas (absorbansi) dari setiap komponen warna.

Hasil nilai intensitas warna RGB NPP terimobilisasi pada kertas saring dengan penambahan larutan stok $\mathrm{Hg}^{2+}$ pada konsentrasi ppb dapat dilihat pada tabel 5 .

Tabel 5. Nilai intensitas warna RGB NPP terimobilisasi pada kertas + larutan stok $\mathrm{Hg}^{2+}(\mathrm{ppb})$

\begin{tabular}{|l|l|l|l|l|}
\hline $\begin{array}{c}\text { Konsentrasi } \\
(\mathrm{ppb})\end{array}$ & \multicolumn{4}{|c|}{ Intensitas Serapan } \\
\hline & \multicolumn{1}{|c|}{$\mathrm{R}$} & \multicolumn{1}{|c|}{$\mathrm{G}$} & \multicolumn{1}{|c|}{$\mathrm{B}$} & Itot \\
\hline 0 & 0 & 0 & 0 & 0 \\
\hline 1 & 0,658 & 5,390 & 3,818 & 9,813 \\
\hline 2 & 7,896 & 10,990 & 14,958 & 33,844 \\
\hline 3 & 10,285 & 11,685 & 18,413 & 40,383 \\
\hline 4 & 15,149 & 19,985 & 26,421 & 61,554 \\
\hline
\end{tabular}

Dari Tabel 5. terlihat bahwa intensitas warna berbanding lurus dengan konsentrasi larutan stok $\mathrm{Hg}^{2+}$ yang ditambahkan, semakin besar konsentrasi maka semakin besar juga nilai intensitas. Perubahan intensitas pada konsentrasi ppb lebih kecil dari pada konsentrasi ppm, ini dikarenakan perbedaan jumlah NPP yang hilang pada kertas saring.

Pada konsentrasi ppb jumlah NPP yang hilang lebih sedikit dibandingkan pada konsentrasi ppm, sehingga perubahan kertas saring pada konsentrasi ppb lebih kecil dari pada konsentrasi ppm.

Single Linier Regression (SLR) merupakan cara analisis data yang hanya menggunakan 1 kurva kalibrasi saja. Pada citra digital data yang digunakan, merupakan data yang memiliki nilai regresi yang paling bagus yaitu $R^{2}$ yang mendekati 1 , bila terdapat kesamaan nilai $\mathrm{R}^{2}$ , maka dipilihlah data yang memiliki kemiringan (slope) yang paling besar.

Dari Tabel 3 dan Tabel 5. dibuatlah kurva konsentrasi terhadap nilai intensitas, pembuatan kurva ini bertujuan untuk mengetahui nilai $\mathrm{R}^{2}$ terbaik dari seluruh data intensitas komponen warna.

Pembuatan kurva ini juga bertujuan untuk melihat persamaan linier yang dibentuk dari konsentrasi terhadap intensitas komponen warna, dari persamaan linier ini didapat kemiringan data kurva yang terbentuk. Kurva yang dibentuk dari Tabel 3 dan Tabel 5. dapat dilihat pada Gambar 3.

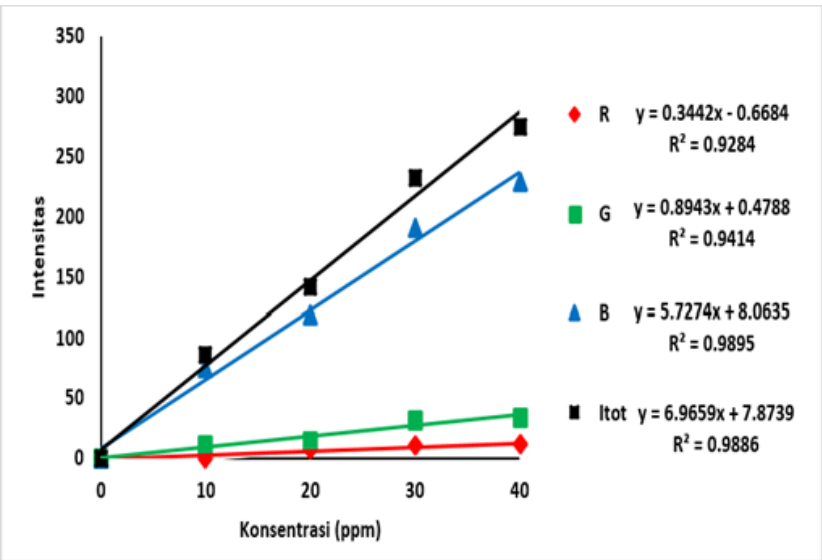

(a)

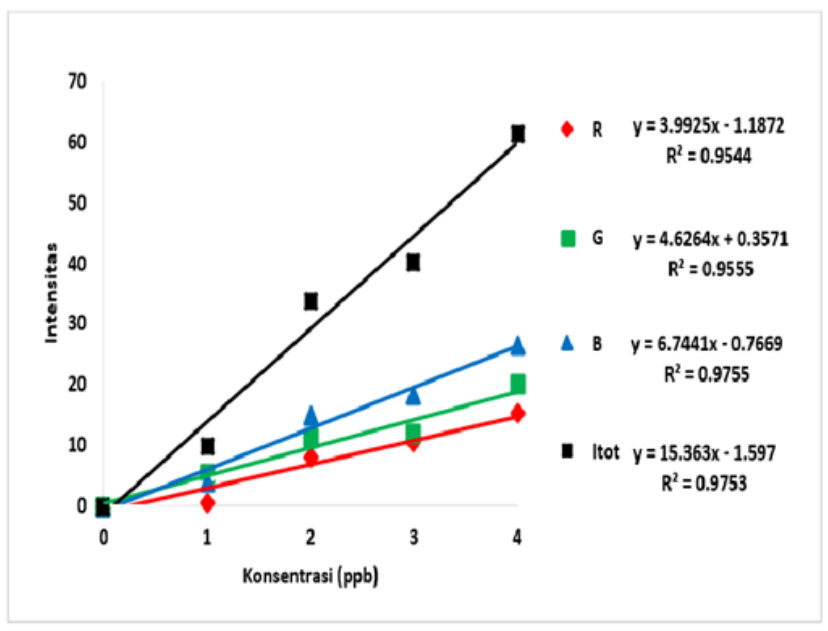

(b)

Gambar 3. Kurva kalibrasi analisis ion merkuri

(II) menggunakan SLR

(a) $\mathrm{Hg} 2+$ pada konsentrasi ppm

(b) $\mathrm{Hg} 2+$ pada konsentrasi ppb.

Dari Gambar 3. terlihat bahwa nilai intensitas komponen blue (B) memiliki nilai R2 yang paling mendekati 1 , untuk larutan stok $\mathrm{Hg} 2+$ pada konsentrasi ppm memiliki nilai $\mathrm{R} 2=$ 0,9895 dan pada konsentrasi ppb memiliki nilai $\mathrm{R} 2=0,9755$.

Maka digunakanlah intensitas komponen B untuk kurva kalibrasi analisis ion merkuri (II), dengan nilai persamaan garis untuk larutan stok $\mathrm{Hg} 2+$ pada konsentrasi ppm yaitu, $\mathrm{y}=5,7274 \mathrm{x}+8,0635$ dan konsentrasi ppb yaitu, $\mathrm{y}=6,7441 \mathrm{X}-0,7669$.

Analisis Principal Component Regression (PCR) pada pengolahan datanya menggunakan seluruh intensitas komponen warna sebagai informasi analasis dalam membuat suatu 
kalibrasi.

Setiap intensitas komponen warna memiliki data informasi yang tersembunyi, yang sangat berguna apabila pada saat pengambilan gambar citra, bila masih terdapat faktor-faktor kesalahan yangterjadi [18].

Pada PCR data asli dikompres menjadi menjadi variabel yang lebih kecil disebut dengan Principal Component (PC) atau komponen utama yang tidak saling berkorelasi pada variabel bebasnya [19], tanpa mengurangi informasi yang ada pada data asli.

Pada penelitian ini pengolahan analisis multivariat menggunakan aplikasi The Unscrambler X 10.4 dari Camo software, USA, yang merupakan aplikasi khusus pengolahan data secara multivariat.

Seluruh data pada Tabel 3 dan Tabel 5. diolah menggunakan aplikasi The Unscrambler X 10.4 untuk menjadi data training set, dimana setelah data diolah didapatlah nilai komponen utama yang digunakan (Gambar 4).

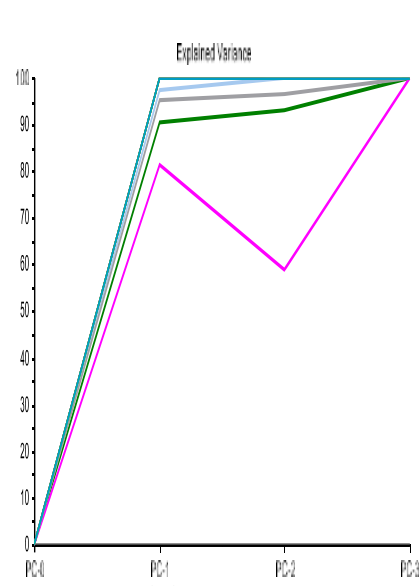

(a)

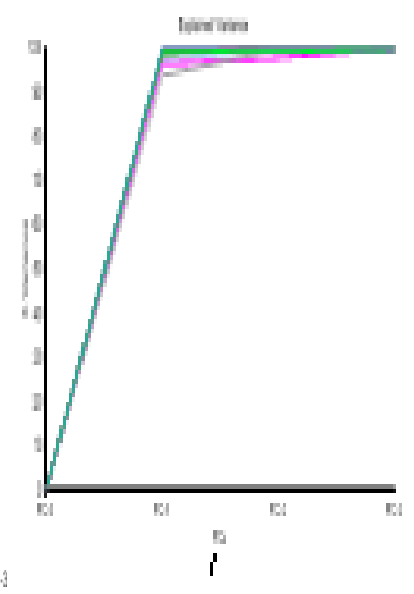

(b)
Gambar 4. Kurva nilai komponen utama (a) $\mathrm{Hg}^{2+}$ pada konsentrasi ppm (b) $\mathrm{Hg}^{2+}$ pada konsentrasi ppb

Dari Gambar 4. didapatlah nilai variasi disetiap komponen utama untuk konsentrasi ppm sebagai berikut : PC-0 $=0 \%, \mathrm{PC}-1=98,8912 \%$,

PC-2 $=99,3198 \%$, dan PC-3=99,3968\% variasi disetiap komponen utama untuk konsentrasi ppb yaitu PC- $0=0 \%$, PC- $1=97,5464859 \%$,

$$
\begin{aligned}
& \text { PC-2 = 97,5681839\%, dan } \\
& \text { PC3 }=398,0649185 \% .
\end{aligned}
$$

Dari data ini PC-0 tidak dapat mewakili komponen yang ada, namun pada komponen PC-1 telah mampu mewakili seluruh komponen yang ada ini terlihat dari data,karena memiiki variasi data yang lebih dari $90 \%$ variasi.

Maka digunakanlah PC-1 dalam membuat kalibrasi. Setelah itu harus dilihat korelasi antara variabel terikat dan variabel bebasnya, ini bertujuan untuk mengetahui apakah data dapat digunakan sebagai data yang memiliki informasi analisis, hubungan korelasi antara variabel bebas dan terikat yang dapat dilihat pada gambar 5 .
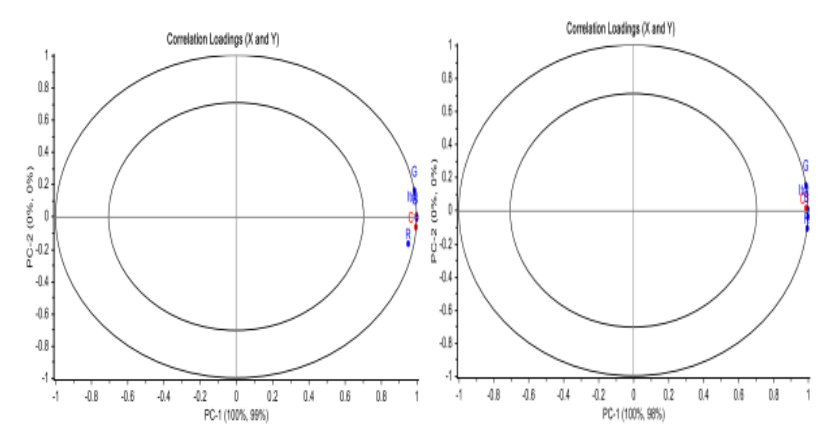

Gambar 5. Hubungan korelasi antara variabel bebas dan variabel terikat secara PCR
(a) $\mathrm{Hg}^{2+}$ pada konsentrasi ppm
(b) $\mathrm{Hg}^{2+}$ pada konsentrasi ppb

Dari gambar 5. terlihat korelasi yang baik antara variabel bebas dan variabel terikat. Konsentrasi yang merupakan variabel bebas berada pada daerah yang sama pada variabel terikatnya red (R), green (G), blue (B), dan Itot.

Karena itu seluruh komponen warna dapat dijadikan informasi anallitis dalam kalibrasi. Dengan menggunakan PC-1 maka didapatlah nilai kalibrasi untuk $\mathrm{Hg}^{2+}$ sebagai berikut

Untuk konsentrasi ppm

$$
\begin{array}{r}
\mathrm{Y}=0,0041 \mathrm{R}+0,0109 \mathrm{G}+0,0688 \mathrm{~B}+ \\
\text { 0,0838 Itot }-0,9955(\mathrm{R} 2=0,97612)
\end{array}
$$

Untuk konsentrasi ppb

$$
\begin{aligned}
\mathrm{Y}= & 0,0123 \mathrm{R}+0,0141 \mathrm{G}+0,0206 \mathrm{~B}+ \\
& 0,0470 \text { Itot }+0,1494(\mathrm{R} 2=
\end{aligned}
$$

$0,9754649)$

Dengan menggunakan PC-1 maka didapatlah nilai kalibrasi untuk $\mathrm{Hg}^{2+}$ sebagai berikut Untuk konsentrasi ppm

$$
\begin{aligned}
& \mathrm{Y}=0,0041 \mathrm{R}+0,0109 \mathrm{G}+0,0688 \mathrm{~B}+ \\
& 0,0838 \text { Itot } \quad-0,9955(\mathrm{R} 2=0,97612)
\end{aligned}
$$

Untuk konsentrasi ppb

$$
\begin{aligned}
& \mathrm{Y}=0,0123 \mathrm{R}+0,0141 \mathrm{G}+0,0206 \mathrm{~B}+ \\
& 0,0470 \text { Itot }+0,1494 \quad(\mathrm{R} 2=0,9754649) .
\end{aligned}
$$

Partial Least Square (PLS) merupakan metode pengolahan data multivariat yang 
membentuk komponen dan dapat menangkap informasi dari variabel bebas untuk memprediksi variabel terikat [20].

Pengolahan data secara PLS, seluruh data pada Tabel 3 dan Tabel 5. diolah menggunakan aplikasi The Unscrambler X 10.4.

Data yang telah diolah menjadi Training Set secara PLS, data ini merupakan kalibrasi yang digunakan dalam menganalisis konsentrasi ion merkuri (II).

Pada PLS seluruh nilai intensitas komponen warna diolah menjadi faktor komponen PLS yang dapat mewakili seluruh faktor yang ada. Setelah itu dilihat nilai faktor komponen PLS yang digunakan dalam kalibrasi pada analisis ion merkuri (II). Kurva nilai dari faktor komponen PLS dapat dilihat pada gambar 6
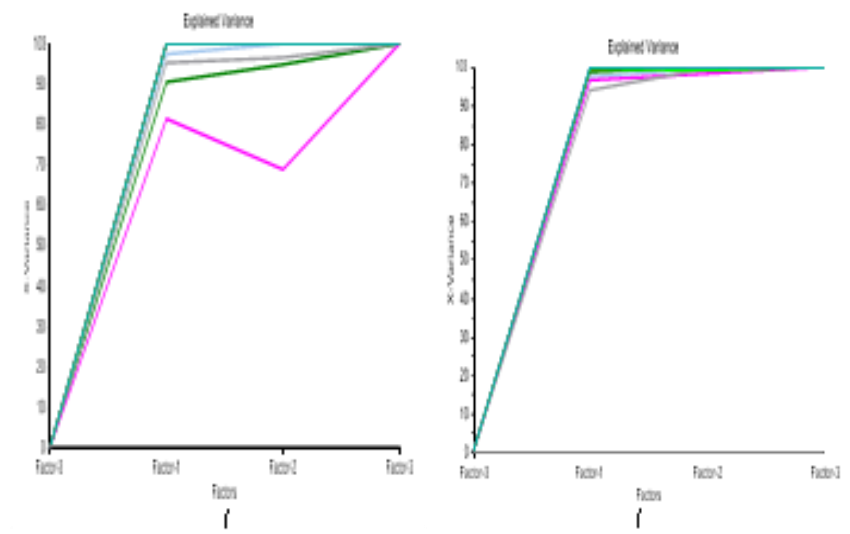

Gambar 6. Kurva nilai komponen PLS

(a) $\mathrm{Hg}^{2+}$ pada konsentrasi ppm

(b) $\mathrm{Hg}^{2+}$ pada konsentrasi ppb

Dari gambar 6. didapatlah nilai variasi disetiap faktor untuk $\mathrm{Hg}^{2+}$ pada konsentrasi ppm yaitu F-0 $=0$ $\%, \mathrm{~F}-1=98,8916 \%, \mathrm{~F}-2=99,3734 \%$, dan

$\mathrm{F}-3=99,3968 \%$, sedangkan untuk $\mathrm{Hg}^{2+}$ pada konsentrasi ppb yaitu $\mathrm{F}-0=0 \%, \mathrm{~F}-1=99,7388 \%$, $\mathrm{F}-2=99,9653 \%$, dan F-3 $=100 \%$.

Dari data ini F-0 tidak dapat mewakili seluruh komponen yang ada, namun pada komponen F-1 telah mampu mewakili seluruh komponen yang ada ini terlihat dari data, karena memiiki variasi data yang lebih dari $90 \%$ variasi.

Setelah itu harus dilihat korelasi antara variabel terikat dan variabel bebasnya, ini bertujuan untuk mengetahui apakah data dapat digunakan sebagai data yang memiliki informasi analisis, hubungan korelasi antara variabel bebas dan terikat dapat dilihat pada gambar 7
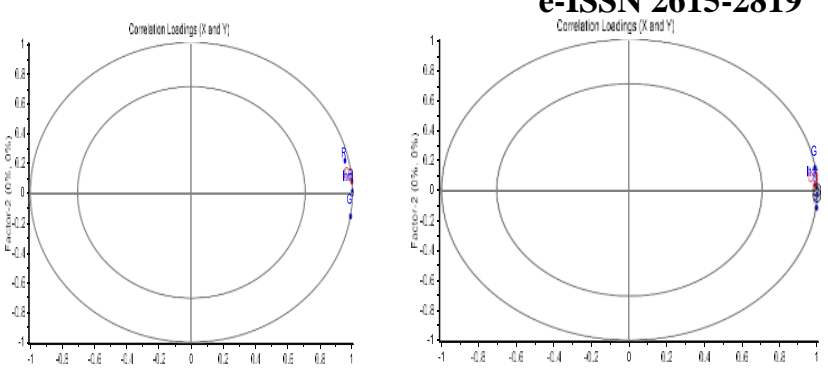

Gambar 7. Hubungan korelasi antara variabel bebas dan variabel terikat secara PLS

(a) $\mathrm{Hg}^{2+}$ pada konsentrasi ppm

(b) $\mathrm{Hg}^{2+}$ pada konsentrasi ppb

Dari gambar 7. terlihat korelasi yang tinggi antara variabel bebas dan variabel terikat. Konsentrasi yang merupakan variabel bebas berada pada daerah yang sama pada variabel terikatnya red $(\mathrm{R})$, green $(\mathrm{G})$, blue $(\mathrm{B})$, dan Itot. Dan seluruh komponen warna dapat dijadikan informasi anallitis dalam kalibrasi.

Dengan menggunakan F- 1 maka didapatlah nilai kalibrasi untuk $\mathrm{Hg}^{2+}$ pada konsentrasi ppm sebesar $\mathrm{y}=0,0041 \mathrm{R}+0,0108 \mathrm{G}+$ $0,0689 \mathrm{~B}+0,0838$ Itot $-0,9956$ dengan $\mathrm{R} 2=$ 0,976117 sedangkan untuk $\mathrm{Hg}{ }^{2+}$ pada konsentrasi ppb sebesar $\mathrm{y}=0,0122 \mathrm{R}+0,0141 \mathrm{G}+$ $0,0206 \mathrm{~B}+0,0470$ Itot $+0,1493$ dengan $\mathrm{R} 2=$ 0,9754675 .

Seluruh teknik pengolahan data yang dikombinasikan dengan metode citra digital harus dicari nilai Limit of Detection (LOD) yang merupakan batas terkecil (kuantitatif) suatu metode dalam menganalisis suatu sampel [21]. Artinya semakin kecil nilai LOD maka semakin bagus metode tersebut dalam analisis kuantitatif.

Dari ketiga metode analisis data didapatkan nilai LOD yaitu SLR 0,837, PCR 0,4311, dan PLS 0,4310. Dari ketiga metode, metode PLS memiliki nilai terkecil dan hampir sama dengan nilai LOD dari PCR. Sedangkan nilai LOD dari SLR menunjukan angka yang cukup besar, jadi PCR dan PLS merupakan metode analisis multivariat terbaik dibandingkan metode analisis SLR.

\section{KESIMPULAN}

Berdasarkan hasil penelitian kemometrik memiliki pengaruh yang baik terhadap tingkat Limit of Detection (LOD) citra digital, dimana tingkat LOD dengan penerapan kemometrik Principal Component Regression (PCR) 0,4311 ppb, dan Partial Least Square (PLS) 0,4310 ppb lebih kecil dibandingkan tanpa penerapan 
kemometrik Single Linier Regression (SLR) 0,837 ppb.

\section{SARAN .}

Perlunya pengolahan gambar lebih lanjut dari hasil foto yang didapat agar kualitas foto meningkat, bisa dengan cara mereduksi noise yang terdapat pada foto. Noise merupakan pengganggu yang dapat merusak nilai intensitas dari komponen warna, sehingga dapat menyebabkan tingkat kesalahan pada pembuatan kalibrasi.

\section{DAFTAR PUSTAKA}

[1] Maleki, N., A. Safavi, F. Sedaghatpur.

Single-step Clibration, Prediction, and Real Samples Data Acquisition for Artificial Neural Network Using a CCD Camera.

Jurnal Talanta, 2004: 64 (1) : 830-835.

[2] Suzuki Y., M. Endo, J. Jin, K. Iwasw., M. Iwarsuki. , Tristimulus Colorimetry Using a Digital Still Camera and Its Application to Determination of Iron and Residual Chlorine in Water Sample. Anal.Sci., 2006: 20(1):411-414.

[3] Bustomi, M.A., Ahmad Zaki Dzulfikar., Analisis Distribusi Intensitas RGB Citra Digital untuk Klasifikasi Kualitas Biji Jagung menggunakan Jaringan Syaraf Tiruan, Jurnal Fisika Dan Aplikasinya, 2014: 10(3): 127-132.

[4] Atmaja, D.S.E., Muhammad Kusumawan Herliansyah.,Optimasi Proses Pengukuran Dimensi Dan Defect Ubin Keramik Menggunakan Pengolahan Citra Digital Dan Full Factorial Design, Jurnal Teknosains, 2015: 4(2): 179-191

[5] Rismiarti,Z.,Renny Indrawati., Karakterisasi Metode Paper Analytical Device Berbasis Pencitraan Digital Untuk Deteksi Kadmium, Chem. Prog. 2017: 10 (2): 52-57.

[6] Akbar, Y.M., Rudiati Evi Masithoh, Nafis Khuriyati., Aplikasi Analisis Multivariat Berdasarkan Warna untuk Memprediksi Brix dan $\mathrm{pH}$ pada Pisang, AGRITECH, 2017: 37(1): 108-114.

[7] Purwakusumah, E.D., Mohamad Rafi, Utami Dyah Syafitri, Waras Nurcholis,
Muhammad Agung Zaim Adzkiya, Identifikasi Dan Autentikasi Jahe Merah Menggunakan Kombinasi Spektroskopi FTIR Dan Kemometrik AGRITECH, 2014: 34(1): 82-87.

[8] Ohyver, M., Pemodelan Principal Component Regression Dengan Software R., ComTech , 2012: 3 (1): 177-185.

[9] Lusiana, V., Teknik Kompresi Citra Digital untuk Penyimpanan File menggunakan Format Data XML,Jurnal Teknologi Informasi DINAMIK, 2014: 19(2): 112-119.

[10] Priadana, A., Agus Harjoko., Deteksi Perubahan Citra Pada Video Menggunakan Illumination Invariant Change Detection, IJCCS, 2017: 11(1): 89-98

[11] Sari, P.I, M.Lutfi Firdaus, Rina Elvia., Pembuatan Nanopartikel Perak (NPP) Dengan Bioreduktor Ekstrak Buah Muntingia calabura L Untuk Analisis Logam Merkuri, Alotrop, 1(1):20-26.

[12] Adriansyah, R., M. Lutfi Firdaus, Elvinawati., Analisis $\mathrm{Hg}^{2+}$ dengan Menggunakan Nanopartikel Perak (NPP) Sebagai Indikator Kolorimetri dengan Metode Spektrofotometri, Alotrop. 2017: $1(2)$ : 136-143.

[13] Maryani, D., M. Lutfi Firdaus, Nurhamidah., Biosintesis Nano Partikel Perak Menggunakan Ekstrak Buah

Passiflora flavicarva (Markisa) Untuk Mendeteksi Logam Berat. Alotrop, 2017: 1(1): 49-54.

[14] Yulianti, R., Emi Sukiyah, Nana Sulaksana., Dampak Limbah Penambangan Emas Tanpa Izin (PETI) Terhadap Kualitas Air Sungai Limun Kabupaten Sarolangun Propinsi Jambi, Bulletin of Scientific Contribution, 2016: 14(3): $251-262$.

[15] Meileza, N., M.Lutfi Firdaus, Elvinawati Analisis Ion Merkuri (II) Menggunakan Nano partikel Perak Terimobilisasi Pada Kertas Saring, Alotrop, 2018:2(2): 191197.

[16] Chen, G.H., Wei, Y.C., Yu, C.Y., Chia, W.W., Huan, T.C., Chien, F.C. Detection of Mercury (II) Ions Using Colorimetric Gold Nanoparticles on Paper-Based Analytical Devices. Analytical Chemistry. 
2014. 16(1): 7-20

[17] Drobina, R., Mieczysław S. Machnio., Application Of The Image Analysis Technique For Textile Identification, AUTEX Research Journal, 2006: 6 (1): 40-48.

[18] Hendrati, D., Abdul Mutalib, Megasari Pratiwi, Retna Putri Fauzia., Penggunaan Kombinasi Metode Spektrofotometri Ultraviolet-Visible Dan Analisis Multivariat Untuk Analisis Kandungan Unsur Tanah Jarang Kelompok Sedang, Chimica et Natura Acta , 2017: 5 (1): 4349.

[19] Wold, S., Kim Esbensen Paul Geladi, Principal component analysis, Chemometrics and Intelligent Laboratory Systems, 1987: 2(1): 37-52.

[20] Nurhasanah, Muhammad Subianto, Rika Fitriani, Perbandingan Metode Partial Least Square (PLS) dengan Regresi Komponen Utama untuk Mengatasi Multikolinearitas, Statistika, , 2012: 12 (1) : $33-42$.

[21] Harmita, Petunjuk Pelaksanaan Validasi Metode Dan Cara Perhitungannya, Majalah Ilmu Kefarmasian, 2004: 1(3): $117-135$.

Penulisan Sitasi Artikel ini adalah

Dinata, A.A., M. Lutfi Firdaus, Rina Elvia., Penerapan Kemometrik Pada Metode Citra Digital Untuk Analisis Ion Merkuri (II) Dengan Indikator Nanopartikel Perak , Alotrop, 2019: 3(1): 105-113. 